\title{
The Impacts of Terrorism and Capitalist Incorporation on Indigenous Americans
}

\author{
Asafa Jalata \\ University of Tennessee, Knoxville \\ ajalata@utk.edu
}

\begin{abstract}
This article demonstrates the connections between terrorism, colonial state formation, and the development of the capitalist world system, or globalization, exploring the consequences of colonial terrorism on indigenous American peoples. First, the piece introduces the central argument and conceptualizes and theorizes terrorism. Second, it examines the structural aspects of colonial terrorism by connecting it to specific colonial policies and practices. Third, it explains the ideological justifications that Euro-American colonial settlers and their descendants used in committing crimes against humanity and dispossessing the homelands of indigenous Americans, as well as in amassing wealth/capital by ignoring moral, ethical, and philosophical issues and human rights.
\end{abstract}

Keywords: colonialism, global capitalism, racism, state terrorism, genocide, indigenous Americans, indigenous movement

Promoting and defending self- and racial-centered interests and accepting culturally and ideologically blind thinking have prevented the Euro-American colonialists, their descendants, and even scholars from critically understanding the meaning and consequences of the violence inherent in Western state formation and in the expansion of the capitalist world-economy - what I refer to as colonial terrorism. By acquiring new territories and obtaining precious resources through colonialism, terrorism, and genocide, the EuroAmericans and their scholars have developed ruling ideas and hegemonic knowledge in explaining, rationalizing, and justifying all forms of colonial projects. In these processes, they objectified indigenous Americans in order to deny them the right to exist in their own homelands and continents by claiming that these peoples lacked histories, humanity, and cultural achievements (Wolf 1982). By degrading and erasing the cultures, histories, and humanity of the indigenous Americans, the settlers and their descendants convinced themselves that they could terrorize, annihilate, and dispossess the resources of these peoples without moral/ethical and political responsibilities. Specifically, because of its rejection of multi-cultural knowledges and wisdoms and its tradition of "abyssal thinking" (Santos 2007), Euro-American hegemonic knowledge could not recognize the humanity of indigenous peoples. Euro-American hegemonic scholarship and the ruling ideas have ignored that the colonized world has been "a data mine for social theory" and the source of objective knowledge production (Connell 2007).

Despite the fact that colonial states and their agencies organized various forms of 
violence, hegemonic scholarship has glossed over the terrorist aspect of the violence and its importance in the broadening and deepening of the capitalist world system. Raewyn Connell (2007) and Bonaventura de Sousa Santos (2007) explain how the hegemonic knowledge of the West limits our understanding of the whole world by ignoring the geo-cultures of indigenous and other subaltern thinkers and framers. In order to critically and thoroughly understand the relationship between global capitalism, colonialism, terrorism, and genocide, we need to stretch our intellectual horizons beyond the limitations of mainstream scholarship and the ruling ideas of the dominant system. This is what I try to do by focusing on the impacts of colonial terrorism and capitalist incorporation on the indigenous Americas.

Since colonial terrorism is one form of terrorism, broadly defining this phenomenon is essential. So, I define terrorism as a systematic governmental or organizational policy or strategy through which lethal violence is practiced openly or covertly to threaten and impose fear on a given population group, beyond its direct victims, to undermine or repress resistance to domination and oppression by a dominant group. Among their many weapons, the Euro-American powers systematically imposed colonial terrorism on the indigenous Americans in order to exploit their economic and labor resources and to ultimately destroy them and take over their homelands.

Without violence, it is impossible to separate people from their homelands, their means of production, or to otherwise deny their human rights. The development of capitalism and the concomitant advancement in technology and organizational structures strengthened the interconnections among world-systemic processes, colonization, incorporation, and the use of terrorist violence to intensify these complex processes.

Generally speaking, there is a lack of consensus on a precise definition of terrorism among the experts of terrorism studies, other scholars, and politicians. Some scholars define terrorism as premeditated or intentional violence by non-state actors that impose fear on a target population in order to achieve certain political objectives (Enders and Sander 2006: 34). Of course, such a definition does not deal with all forms of terrorism since it only focuses on non-state terrorism. A great number of experts define terrorism without identifying its agent (Cooper 2001). Richard Jackson (2009: 174) argues that terrorism is "the intrusion of fear into everyday public and private life, the denial of the right to live free from fear and the erosion of the capacity, for clearly thinking and unimpeded decision making." Although several representative definitions of terrorism converge on the notion that terrorism is "the deliberate use of violence in order to influence some audience (or audiences)" [author's emphasis], these definitions diverge on several issues, such as which agents engage in terrorism and who can be its target (Goodwin 2006). Many scholars and other experts of terrorism studies do not adequately explore the role of state terrorism in the creation and maintenance of the capitalist world system, and they focus on non-state terrorism. But in reality both state agencies and non-state actors engage in terrorism, although the impacts of the former are greater than those of the latter (Sloan 1984: 84).

Some critical scholars, not limited by their social locations and geo-cultures, have characterized capitalist expansion as a form of violence, or even terrorism. For instance, Tony Barta points out that "Arendt brought us closer to historical understanding of the murderous progress of modernity, by relating... genocide in the colonies to developments far away" (2007: 100). For Escobar, capitalist development, perpetual violence, and globalization are inseparable $(2004 \mathrm{a}, 200 \mathrm{~b})$. Farmer notes that various forms of violence and dispossession that started in the late fifteenth century still continue in the Americas $(2004,2005)$. McMichael focuses on the roles of racist and modernist ideology and massive violence that the West has used in dehumanizing and impoverishing indigenous peoples for more than five centuries (2006). Scholars such as Blakeley (2009) and Curtis $(1995,1998)$ explore how the global North, particularly the United States and the United Kingdom, have been contributing to 
gross human rights violations and state terrorism in the global South. Blakeley (2009: 4) provides "a detailed history of Northern state terrorism, within the context of the foreign policy objectives of those states and the strategies they use to achieve them, dating back to the European colonial era, through to the practices of the US and its allies in the "War on Terror." Jalata explains the relationships among global imperialism, dependent colonialism, and colonial terrorism in Oromia (the Oromo country), Ethiopia, and the Horn of Africa $(2000,2006)$.

Elkins (2005) discusses the role of British colonial government in using political terror to destroy a Kenyan liberation movement. Western powerful states still engage both directly and indirectly in various forms of terrorism to dominate economic resources and markets in the Global South. Since the 1970s, with the intensification of the crisis of capital accumulation and the decline of the US hegemony in the modern world system, the West under the leadership of the United States started to promote a policy known as neoliberalism to revitalize global capital accumulation (Harvey 2005). As David Harvey (2005: 7) demonstrates, through the policy of neoliberalism the neoliberal state has intensified the process of capital accumulation by dispossessing ordinary individuals and groups of their economic resources and rights through all forms of violence: the "fundamental mission [of the neoliberal state] was to facilitate conditions for profitable capital accumulation on the part of both domestic and foreign capital." Further, Berch Berberoglu (2003: 108) writes that "the process of integration of neocolonial states into the global economy, seeking the protection of the imperial state, has been to a large degree a reaction to a perceived threat to the survival of capitalism in the Third World-one that is becoming a grave concern for both imperialism and the local repressive capitalist states." Terrorism has thus been an integral part of the capitalist world-system from 1492 till today. Although the competing European colonial forces initially used contacts, cooperation, exploration, trade, and diplomatic mechanisms such as negotiations, treaties, and land cessions, as well as different forms of violence, their main political tool for dispossessing, destroying, and/or suppressing indigenous communities and establishing settler colonialism and its institutions in the Americas was colonial terrorism.

Obviously, at this historical period there was no legal conception of crimes against humanity, and the ways such crimes have been conceptualized and defined remains problematic, since states that have been implicated in all form of violence have been the authors and interpreters of international law. The contradictions between hegemonic and counter-hegemonic international laws must be rethought and reformulated to promote humancentric sustainable development and human rights laws and eliminate the gap between the theories of human rights and its practices (Rajagopal 2003: 2006). In 1948 the adoption of the Convention on the Prevention and Punishment of the Crime of Genocide defined genocides as "acts committed with intent to destroy, in whole or in part, a national, ethnical, racial or religious group." When "state terrorism can be seen as a method of rule whereby some groups of people are victimized with great brutality, and more or less arbitrarily by the state or state supported actors, so that others who have reason to identify with those murdered, will despair, obey or comply" (Schmid, 1991: 31), genocide can be considered as the elimination in part or in whole of a certain group of people in order to expropriate their resources or stop their resistance to the state or the agents of the state (Lemkin 1944; Kuper 1981; Jonassohn 1998: 9).

According to Frank Chalk and Kurt Jonassohn (1990: 23), "GENOCIDE is a form of one-sided mass killing in which a state or other authority intends to destroy a group, as that [group] and membership in it are defined by the perpetrator." Genocide, terrorism and war are thus interconnected. Since war and terrorism can be seen as a continuous process, it is often impossible to draw a clear boundary between political repression, state terrorism, war, 
and genocide. With the formation of nation-states and the modern world-system, colonial terrorism and genocide expanded all over the world since the sixteenth century (Frank 1978: 51-52). A few scholars, such as Raphael Lemkin (1944), Leo Kuper (1981), David E. Stannard (1992), Russell Thornton (1987), Irving Louis Horowitz (2002), Samuel Totten Steven and Leonard Jacobs (2002), and others have documented the crimes of states in forms of genocide and other gross human rights violations. Similarly, social movement scholars, such as Sonia E. Alvarez and Arturo Escobar (1992), Deborah J. Yashar (2005), Donna Lee Van Cott (2007), Alison Brysk (2000), Franke Wilmer (1993), Margaret E. Keck and Kathryn Sikkink (1999), A. Kim Clark and Marc Becker (2007), Suzana Sawyer (2004), and others have written about colonial atrocities against indigenous peoples. However, these scholars do not link terrorism, colonial state development, capitalism, and genocide. As capitalism emerged and developed in Western Europe, the need for raw materials, such as gold and silver, food, markets, and free or cheap labor expanded due to the desire to minimize the cost of production and to increase the rate of profit and accumulation of capital/wealth.

These needs were fulfilled through colonialism, racial slavery, terrorism, and genocide (Jalata 2001; 2011). "The treasures captured outside of Europe by undisguised looting, enslavement, and murder," Karl Marx (1967: 753-754) writes, "floated back to the mothercountry and were there turned to capital." Capitalism saw its "first long, sustained, and widespread quantitative and qualitative development... in its mercantile stage and the first period of concentrated capital accumulation in Europe" (Frank 1978: 52). Western powers and states in the global South still engage in terrorism and genocide to implement their draconian economic and political policies. Furthermore, the West uses "the economic weapons of the international financial institutions" and other means, such as the "the war on terrorism," to continue its war on social justice (Eisenstein 2001: 136). Western powers, multinational corporations, the World Bank, the IMF, and state elites in the Global South have collaborated and engaged in massive human rights violations and terrorism (Blakeley 2009) even as Western-based human rights organizations have systematically exposed such crimes. Overall, colonial terrorism, capitalist incorporation, and the maintenance of the capitalist world-system have been inseparable global processes since the late fifteenth century. As demonstrated below, the social history of the indigenous Americans demonstrates these processes.

\section{Colonial Terrorism and Capitalist Incorporation}

A few world-systems analysts and other critical scholars have explored some aspects of colonial violence during different phases of the incorporation of indigenous peoples into the European-dominated capitalist world-system. However, they do not adequately explain that the extermination of the indigenous Americans and the implementation of the capitalist system in the Americans involved colonial terrorism and genocide. As Blakeley notes,

Violence against the indigenous populations [. . .] involved the initial terrorising of the indigenous populations into supplying conquerors with food supplies, threatening them with death if they did not acquiescence, and the wiping out of whole [cultural groups] that were deemed of no use to the economic projects of the European settlers. Those that did survive were terrorized into forced labour, often as slaves, as part of the imperial efforts of [the European crowns]. (2009: 55) 
Scholars such as R. Brian Ferguson and Neil L. Whitehead (1992), Eric Wolf (1982), and others who tried to explain the impacts of colonial violence on indigenous peoples did not go far enough to explain the essence and consequences of colonial terrorism. The colonial powers could not defeat indigenous Americans without imposing fear through various forms of violence, including terrorism.

When indigenous groups were coerced through various forms of terror to provide their economic resources, such as food items, land, and labor to the European colonizers, neighboring populations would "witness the violence and would then be sufficiently terrorised into providing the resources demanded by the colonisers, or face the same violence outcomes" (Blakeley 2009: 56). The incorporation of indigenous Americans into the European-dominated capitalist world-system resulted in repeated warfare among indigenous Americans and between Europeans and indigenous peoples, causing social and institutional disruption and devastation (Dunaway 1994; 1996a). It also resulted in the development of the racialized capitalist world-system and colonial state formation through "violent expansion [that] included a land takeover literally on a continental scale, massive labor exploitation systems including genocide or slavery, natural resource extraction that fueled industrialization, and development of large states" (Hall and Fenelon 2004: 155). For instance, from 1503 to 1660 , the Spanish colonialists amassed 185,000 kilograms of gold and 7 million pounds of silver (Elliot 1996: 180); from 1760 to 1809, they expropriated from the Zacatecas and Guanajuato of Mexico mines gold and silver valued for more than $\$ 5$ billion (Green Left 1992). As Eduardo Galeano observed, "gold and silver were the keys used by the Renaissance to open doors of paradise in heaven and of capitalist mercantilism on earth" (1997: 14).

Furthermore, colonialists forced the surviving indigenous peoples and enslaved Africans to mine bullion and produce crops, such as sugar, cotton, rubber, and food in large quantities. They defeated native peoples by terror because they had "armor and coats of mail, lustrous caparisons that deflected arrows and stones; their weapons emitted deadly rays and darkened the air with suffocating smoke" (Galeano 1997: 17). Juan-Carlos Córdoba (2007) demonstrates the relationships among colonialism, transoceanic trade, technological and institutional developments, the Industrial Revolution in Atlantic Europe, and the consolidation of the capitalist world-system between 1500 and 1850. Regarding the so-called discovery of the Americas, Galeano asserts that

everything, from the discovery until our times, has always been transmuted into European - or later United States - capital, and as such has accumulated in distant centers of power. Everything: the soil, its fruits and its mineral-rich depths, the people and their capacity to work and to consume, natural resources and human resources. (1997: 2)

European and American states and their agents used colonial terrorism in dispossessing people of their lands, committing genocide, and in reorganizing peoples on a racial criterion, and "these processes coincided with the spread of European diseases, which tore apart the social fabric, especially the system of marriage alliances" (Hall 1993: 243).

The spread of European diseases was extended for many centuries, as 'contact' actually refers to a "temporally extended process, rather than a single instant or event that ruptured the otherwise pristine Garden of Eden into which the Europeans at first believed they had stumbled" (Whitehead 1993: 288). Sometimes, European and African diseases affected indigenous Americans who had not encountered any person from the European and African continents; since the spread of epidemics was not uniform, the transmission rates were "affected by diet, physical settings, social practices and active native responses to 
epidemics" (Whitehead 1993: 289). Some colonial forces used smallpox as warfare to eradicate some indigenous Americans (Fenn 2000). In addition to colonial terrorism, "the introduction of new pathogens was probably the single most dramatic source of change in Indian Society, within a century reducing native population to about one-tenth of its former extent" (Hall 1989a: 71). The destruction of indigenous ecosystems, "germ colonization," warfare, slavery, famine, and alcoholism dramatically depopulated indigenous peoples (Dunaway 1996a, 1996b).

\section{Colonial Terrorism and the Emergence of Spanish America}

Initially the Spaniards moved from place to place, destroying the indigenous Americans through several terror tactics, including torture. As Blakeley states, torture was a tool of terrorism, "carried out by representatives of the state against civilians to instill fear for political purposes" (2009: 228). The complex processes of incorporation started on April 17, 1492 when Queen Isabel and King Ferdinand of Spain granted Christopher Columbus the privileges of exploring, colonizing, and plundering by financing his expeditions. The monarchs appointed Columbus as the Admiral of the Ocean Sea, promising him 10 percent of the profits from gold and spices he would bring back and appointment as governor over new areas he would colonize (Zinn 2003: 2). On October 12, 1492, Columbus's expedition's three ships accidentally arrived in the so-called Indies, as Columbus claimed to have "discovered" Asia. When they first arrived, "the Spaniards were favorably received and entertained by the Arawak people, who traded food and water and a few gold ornaments for such trifles as newly minted copper coins, brass bells and even bits of broken glass and pottery" (Cohen 1969: 17-18). Columbus called the Indies "the earthly Paradise" (Cohen 1969: 19), and wrote a letter explaining the behaviors and conditions of the Arawak people as he understood them: "They have no iron or steel or arms... All the weapons they have are canes cut at seeding time, at the end of which they fix a sharpened stick, but they have not the courage to make use of these" (Cohen 1969: 17-18).

Assuming that the Arawak people and others could not defend their homelands from the invading Spaniards, Columbus wrote a letter to the monarchs of Spain stating that "I found very many islands with large populations and took possession of them all for their Highnesses; this I did by proclamation and unfurled the royal standard. No opposition was offered" (Cohen 1969: 115). The Spaniards characterized one of the indigenous groups called the Caribs cannibals and singled them out for annihilation (Josephy 1991). The Caribs suffered at the hands of the Spaniards and other Europeans:

Spanish, French, and English invaders, colonizers, pirates, and imperial exploiters all but exterminated them, slaughtering Caribs wholesale with fire, steel, European torture, and wiping out their settlements with the pox, measles, diphtheria, and other white men's diseases to which the Indians had no resistance. (Josephy 1991: 3)

The Spaniards imposed terror on the peoples they encountered to frighten the surrounding peoples and reduce their will to resist colonization (Blakeley 2009: 56-57). To prove the profitability of his expeditions to his sponsors, Columbus frequently sent to Spain cargoes of gold, other valuables, and slaves that he obtained through terrorizing the indigenous Americans. Initially his main goal was to obtain gold. He captured some indigenous peoples as soon as he arrived in the Indies to collect information from them on its sources (Zinn 2003). This first expedition set the stage for "the racism and savagery of the world conquest" (Chomsky 1993: 5). 
The arrival of Columbus and his sailors in the Indies thus brought disaster and violence, including colonial terrorism, to the peaceful and generous Arawak people and others. At the beginning, without knowing with what kind of people they were dealing, native peoples peacefully traded with and even brought food and gifts to Columbus and his sailors "because of their culture of hospitality and their belief in sharing" (Zinn 2003: 1). The Spaniards, however, considered the kindness and hospitality as backwardness and weakness and took advantage of the people by intimidation, force and terrorism. Columbus thus established the first colony early in 1494 on the island of Hispaniola (now Haiti and the Dominican Republic), and collected a sizable amount of gold to ship back to Spain. With his associates, he continued to use terrorism to obtain more food, gold, women, slaves, and lands. In 1495, the Spaniards went from island to island taking indigenous Americans, known as the Taino people, as captives and taking women and children as slaves for sex and labor: "Some of the captives were forced to wear copper tokens on their necks . . those who were "found without a copper token had their hands cut off and bled to death" (Zinn 2003: 4). The Spaniards forced the indigenous peoples to work on mining of gold and silver and agriculture to grow crops, cotton, and sugar cane; in almost two decades their population shrank "from a quarter of a million to fourteen thousand; in a few more years they had become extinct" (Debo 1995: 19-20).

There were also other estimates for the Taino population during this period; one estimate puts the size of the population between a few hundred thousand and 8 million during pre-Columbus period (The Healing Center 2007: 10-12). The Spanish priest Barttolomé de Las Casas (1971) estimated the deaths of Taino by war, slavery, diseases, and the mines at 3 million. Forced labor and all forms of violence gradually caused the destruction of the indigenous peoples. As we shall see below, the Spaniards and other European groups continued the projects of terrorism, slavery and genocide. As de Las Casas testified: "They forced their way into native settlements, slaughtering everyone they found there [...] Some they chose to keep alive and simply cut their wrists, leaving their hands dangling, saying to them: 'Take this letter' - meaning that their sorry condition would act as a warning to those hiding in the hills" (1992: 15). All these crimes against humanity were intended to terrorize and defeat the surrounding populations. Although "it is beyond human capacity to compile an accurate log of the murder, cruelty, false imprisonment and other crimes committed" (de Las Casas 1992: 37), let me further explain the essence and consequences of colonial terrorism in the Indies and other places. The Spaniards used the strategy of terrorism "in all lands they invaded: to stage a bloody massacre of the most public possible kind in order to terrorize those meek and gentle people" (de Las Casas 1992: 45).

As de Las Casas testified, "the indigenous peoples never did the Europeans any harm whatever" (1992: 13). But the settlers and their descendants terrorized indigenous peoples and raped their girls and women for not only sexual gratification, but in order to perpetuate violence. "The serial rape of captive Indian women became ritualized public spectacles at [...] trade fairs," Ned Blackhawk (2006: 77) writes, "bringing the diverse male participants [...] together for the violent dehumanization of Indian women." Terror and genocide studies ignore

the full extent of the humiliation of the ethnic group through the rape of its women, the symbols of honor and vessels of culture. When a woman's honor is tarnished through illicit intercourse [...] the ethnic group is also dishonored. The after effects of rape-forced impregnation, psychological trauma, degradation, and demoralization-go beyond rape victims themselves. (Sharlack 2002: 107) 
When the Spaniards needed more and more lands and labor of the indigenous peoples to build their expanding colonial settlements, the latter began to realize the essence of their agendas (de Las Casas 1971: 121). As the indigenous peoples refused to supply food and labor for the Spaniards, the latter intensified the use of violence and intimidation. Practically "every Spaniard went out among the Indians robbing and seizing their women wherever he pleased, and doing them such injuries that the Indians decided to take vengeance on any Spaniards they found isolated or unarmed," even killing some of them (Cohen 1969: 187).

The Spaniards used varied tactics of terrorism and warfare for annihilating indigenous peoples. They recruited and mobilized warriors of one indigenous group against the other to divide and conquer through mutual self-destruction:

this fighting generated many captives who could be traded to Spaniards who would ask no questions and pay in horses and guns [...] As both raiding and trade increased, more and more horses and guns came into Indian hands, making formidable foes of formerly annoying attackers and intensifying intergroup fighting. Horses and guns became vital necessities for any group that wished to remain safe and free. (Hall 1989a: 68)

Consequently, some indigenous warriors enslaved and merchandized their war captives, collaborating with competing European colonial powers. The Spaniards intensified their tactics of terror; at least once, they

built a long gibbet, low enough for the toes to touch the ground and prevent strangling, and hanged thirteen [indigenous Americans] [...] When the Indians were thus still alive and hanging, the Spaniards tested their strength and their blades against them, ripping chests open with one blow and exposing entrails $[\ldots]$ Then, straw was wrapped around their torn bodies and they were burned alive. (de Las Casas 1971: 121)

The Spaniards first focused on establishing their colonial settlements in the Greater Antilles (the four largest islands in the Caribbean Sea and included Cuba, Hispaniola, Haiti, and the Dominican Republic, Jamaica, and Puerto Rico) that led to the decimation of the indigenous people by warfare, diseases, and slavery or forced labor (Wilson 1997: 7). After 1620, the Lesser Antilles - included the smaller islands of the Caribbean, the Virgin Islands, the Windward Islands and Leeward Islands - became a contested area for colonization by the French, Dutch, and English and other European groups. Ricardo Alegría asserts that the Spaniards'

eagerness to impose their religion and to obtain the greatest possible profits, were far from scrupulous in their treatment of the natives. Indeed, their cruelty hastened the disintegration of the native culture and its eventual annihilation. By 1510 the Indian population of the islands was almost totally extinct, and colonizers had to import natives from South America to work in the Antillean gold mines. (1997: 12)

Within twenty years, the conquistadors colonized the islands of Hispaniola, Jamaica, Puerto Rico, and Cuba, captured Mexico in 1519 and Guatemala in 1523, and dramatically reduced the size of the indigenous population through enslavement, deportation, and other forms of terrorism. Spanish colonial authorities used Christianity to justify their domination of indigenous groups. According to Neil L. Whitehead, "Evangelism was itself often a military 
process, and where it was successful it exacerbated existing intertribal divisions or even opened new divisions within the discrete tribal structures that had been created by the first phase of conquest and occupation" (1992: 147).

When the settlers exhausted the exploitation of bullion, they began to use indigenous peoples as slave labor for agriculture (Zinn 2003). As de Las Casas observed, "The reason the Christians have murdered on such a vast scale and killed anyone and everyone in their way is purely and simply greed. They have set out to line their pockets with gold and to amass private fortune as quickly as possible so that they can then assume a status quite at odds with that into which they were born" (1992: 13). By 1542 the Spanish colonizers had killed more than twelve million people in the Caribbean, Mexico, and Central America (Kiernan 2007: 77). To impose terror and fear on the surrounding population groups, the Spaniards started flogging, beating, thrashing, punching, cutting the legs or hands off, burning and roasting them alive, butchering babies and throwing them to wild dogs.

In the process, the Spanish settlers had lost their own humanity and "had become so anaesthetized to human suffering by their own greed and ambition that they had ceased to be men in any meaningful sense of the term and had become, by dint of their own wicked deeds, so totally degenerated and given over to a reprobate mind" (de Las Casas 1992: 3). De Las Casas (1992:103) also expounds "that the longer men have operated in the New World and the more they have become accustomed to the carnage and butchery around them, the more brutal and more wicked have been the crimes they commit against God and their fellow-men [and women]." Seen from this angle, the conquistadors were criminals who deliberately engaged in terrorism, genocidal massacres, and extermination through different mechanisms (Kiernan 2007).

They burned people alive or cut them to pieces or tortured them or killed them by swords to terrorize and frighten the surrounding population groups. Men were separated from their wives and communities to work the soil or to mine bullion; they were not allowed to take care of their families and communities. Mothers were also overworked and famished and had no milk; consequently, their newly born babies perished. Beginning in 1514, the Spaniards developed a new policy known as a repartimiento after annihilating most of the indigenous peoples; they divided the lands of the indigenous peoples and the survivors among the settlers to work as semi-slaves in encomienda.

The settlers put men to work in gold mines and sent women 'into the fields of the big ranches to hoe and till the land,' preventing them from cohabiting and having children. Men and women died 'from the same causes, exhaustion and hunger.' Cruelty, violent greed, and the imposition of agricultural serfdom all took their continuing genocidal toll (Kiernan 2007: 86).

The indigenous of Central America were hunting and agricultural communities with a few complex empires such as Aztec and Inca. Jared Diamond notes that the Inca emperor Atahualpa was "absolute monarch of the largest and most advanced state in the new world," and this monarch with his army of 80,000 soldiers confronted the Spanish conquistador Francisco Pizzarro in 1532 (1999: 68).

This powerful monarch was only defeated because of the Spaniards' superior weapons. Various Spanish forces continued to terrorize and extract economic resources of the indigenous Americans; Spanish merchants and landlords from Spain financed the expedition of Hernando Cortés to extract gold and other resources. To further these objectives, "Cortés [...] began his march of death from town to town, using deception, turning Aztec against Aztec, killing with the kind of deliberateness that accompanies a strategy - to paralyze the will of the population by a sudden frightful deed" (Zinn 2003: 11). With an army of 400, 
Cortés started his "spectacularly brutal campaign" to colonize Mexico in April 1519 with the help of his coastal native allies. He first attacked and terrorized the kingdom of Anahuac and its capital, Tenochtitlan, and then annihilated the Otomi people by lancing, stabbing, and shooting them with iron bolts, crossbows, and guns (Kiernan 2007: 88). The conquistadors captured Tlaxcala, killing thousands of people and burning thousands of houses. After reaching the city of Cholula in October 1532, the Spaniards massacred its residents and destroyed the town. One official of Cortés noted that the conquistadors "were dripping with blood and walked over nothing but dead bodies" (quoted in Kiernan 2007: 90).

Cortés and his army furthered the conquest of the areas that became Guatemala and Colombia by sending his lieutenant, Pedro de Alvarado, with 120 cavalry, 300 infantry, and four artillery pieces to repeat the butchery of the indigenous in Mexico (Kiernan 2007). The colonial terrorists needed human trophies to show to and terrorize the surviving population; they also used these trophies to demonstrate their achievements and convince the colonial governors that they accomplished their missions. Using their knives and "approaching the victims and pulling up their heads by the hair, they swiftly removed tender cartilage from the skulls of all the dead. After filling their sacks with the lightweight, blood harvest, the attackers returned to camp and prepared for another campaign" (Blackhawk 2006: 16). The barbarism and cruelty of these terrorists were also demonstrated by their displays of strings of dried ears in their homes (Blackhawk 2006). The Spaniards totally controlled the city of Tenochtitlan and Ixtapalapa; in 1521 they destroyed Ixtapalapa by indiscriminately killing its people and reducing it to "human wreckage" (cited in Kiernan 2007: 91). The de Soto expeditions also exterminated the entire indigenous population of the Southeast of North America (Hollis 2005). Yet, it was not only the Spaniards who committed horrendous crimes against humanity in South and Central America.

\section{Portuguese Colonial Terrorism and the formation of Colonial Brazil}

The colonial Portuguese engaged in similar colonial terrorism and genocide in the area that is called Brazil today. With increased competition from Spain, France, and England to colonize Brazil, Joăo III, the king of Portugal, granted to Martin Afonso de Sousa the right to establish the first official colony in Brazil at Saŏ Vicente. Then within short time the Portuguese monarch announced his plan to colonize all Brazil, "already inhabited by hundreds of Indian groups" (Metcalf 2005: 77). The Portuguese settlers established alliances with indigenous American groups, such as the Tupinikin, through marriage strategies as headmen "adopted" outsiders as son-in-laws. These alliances gradually assisted the expansion of Portuguese colonization, and "the captaincy of Săo Vicente had six hundred colonialists, three thousand slaves, and six sugar mills [in 1548]. These slaves were Indians from traditional enemies of the Tupinikin" (Metcalf 2005: 79). The private colonization initiative was not successful, so the Portuguese king sent his governor to build the capital city in Brazil and to expand Christianity. According to Alida C. Metalf (2005: 83), "The justification for the colonization of Brazil [...] was no simple possession but evangelization. It quickly became apparent that it was not enough for the Tupi-Guarani speaking peoples to supply brazilwood and labor for the Portuguese. They were now expected to accept and practice Christianity."

The Portuguese promoted Christianity and racial slavery simultaneously. Racial slavery was "firmly rooted in Brazil, where it would be the foundation of Brazil's economic development for nearly four hundred years" (Metcalf 2005: 157). These colonists enslaved the Tupi, Guarani, Gê, and Arawak peoples, and these "slaves cleared the first fields and planted them with sugarcane; Indian slaves built the first mills and produced the first sugar harvest. [Enslaved Africans] joined Indians on the sugar plantations in the first half of the sixteenth century, and the numbers increased rapidly after 1550" (Metcalf 2005: 158). Both 
slavery and diseases that were brought to Brazil from across the Atlantic led to the rapid decline of the indigenous peoples during the second half of the sixteenth century.

Unlike Spanish America, where epidemics accompanied colonization, the first epidemics that likely occurred in Brazil before 1550 did not destroy the political or social structure of independent indigenous groups [...] But between 1550 and 1580, Brazil began to follow a pattern similar to that seen in the Spanish Caribbean in the thirty years after 1492: significant outbreaks of disease coincided with the ratcheting up of the tempo of colonization. (Metcalf 2005: 120)

Gradually colonial terrorism, racial slavery, and diseases decimated the indigenous peoples of Brazil.

\section{Violence, Genocide, and the Formation of Colonial States in North America}

The processes of colonization, incorporation, and terrorism gradually moved from South and Central America to North America. Thomas D. Hall (1989a: 17-18) notes that incorporation of North America started with exploration and trade that had serious impacts on lifestyles, security, tastes, social organizations, and communities. Despite the fact that Sir Walter Raleigh attempted to create an English colony at Roanoke in 1584 on the coast of North Carolina, the English did not successfully establish a colony until 1607, when the Virginia Company under the leadership of Captain John Smith established this first settlement in Jamestown, Virginia. After settling in Jamestown, the English expanded their settlements, leading to the opposition of the Powhatan people. As this Virginia settlement grew from 1,300 in 1625 to 8,000 in 1640 , the settlers' policy "did not seek the Powhatans' total extermination, but it required their full subjugation, and eventual slavery for survivors" (Kiernan 2007: 223). Gradually, however, the Powhatans were annihilated (Kiernan 2007). English settlers continued to confiscate the lands of indigenous peoples by using colonial terrorism.

In 1621, English pilgrims also settled at Plymouth, in a section of the continent that later became New England, where they pursued policies of terrorism, extermination, and slavery on the Wampanoag, Narragansett, Pequot, and other indigenous peoples. To transfer the communal ownership of the lands of these peoples, the Puritans "developed a tactic of warfare used by Cortés and later [...] even more systematically: deliberate attacks on noncombatants for the purpose of terrorizing the enemy" (Zinn 2003: 14).

John Winthrop, the governor of the Massachusetts Bay Colony, "created the excuse to take Indian land by declaring the area legally a 'vacuum.' The Indians, he said, had not 'subdued' the land, and therefore had only a 'natural right' to it, but not a 'civil right.' A 'natural right' did not have legal standing" (Zinn 2003: 14-15). By abrogating the communal land rights of the Pequot and Narragansett peoples, Winthrop justified the establishment of private property through violence and expropriation. The Puritans asserted that the heathens who resisted the power of Europeans, God's children, should be condemned and lose their lands violently. In the seventeenth century, the Spaniards, English, French, Russians, and Dutch simultaneously began to establish their permanent colonies in the area north of Mexico. As the English settled at Jamestown in 1607, the French founded Québec in 1608. However, the French had arrived in North America around 1524 in the region presently called Canada, and their explorers such as Jacques Cartier and Samuel de Champlain established business relationships with indigenous American peoples from the Upper Northeast down the Mississippi River and New Orleans. The Russians also established fur- 
gathering posts on the Alaska Peninsula, where they exterminated the Aleut people and "treated them with unspeakable cruelty; they raped the women and held them as hostages until the men ransomed them with furs; they destroyed settlements and murdered people from sheer barbarity. It is estimated that the population when they came was 25,000 ; a count made in 1885 showed 3,892" (Debo 1995: 83).

As we saw above, European powers used diplomatic intrigue to incite indigenous American nations to fight against one another and thereby advance their respective colonial interests. Angie Debo notes that

the imperial rivals used their colonies as footholds from which they worked to outdistance their adversaries and enlarge their dominions by bringing as many native [groups] as possible into their spheres of influence-obtaining their trade, inciting them to war against their opponents or the Indian allies of their opponents, and reducing them to protectorate. (1995: 69)

Thereby indigenous Americans were reduced to serfdom or enslaved or exterminated. The economic and labor exploitation of the indigenous Americas gradually transformed western European countries such as Spain, England, and France and "gave to commerce, to navigation, to industry an impulse never before known" (Loewen 1995: 69). The competing imperial powers introduced competition to the indigenous peoples by changing their lifestyles and tastes through new technology of house building, farming, domestic animals, European fruits, hunting, cooking, and luxury items such as rum or whisky (Debo 1995: 69-70). Consequently, various nations, for perceived or small material benefits, "allied with rival powers scalped each other or fell upon outlying white settlements with fire and death" (Debo 1995: 70). After the thirteen English colonies emerged as the United States following the American Revolution of 1776, the colonial settlers continued to expropriate the lands of indigenous Americans under different ideological pretexts.

The United States began to expand to the Pacific west coast by terrorizing indigenous American peoples and by expropriating their homelands. White Americans convinced themselves that it was God's will for them to control from the Atlantic Sea to the Pacific Sea and later across the continent and beyond. The United States also intensified terrorism on indigenous peoples within its geo-political territories and its neighbors, opening up western frontiers later in Texas, California, and the Great Plains to confiscate lands and other resources. American apartheid and sexist democracy under the leadership of George Washington, John Adams, Benjamin Franklin, Thomas Jefferson, and others promoted colonial terrorism, war, expansion, and genocidal massacres on indigenous Americans. Soldiers, vigilante groups, and other settlers burned villages and towns, destroyed cornfields, massacred women, old men, and children, and scalped their heads for trophies. In 1779, George Washington declared war on the six nations of the Iroquois Northwest and ordered troops to "ruin their crops now in the ground and prevent them planting" (Kiernan 2007: 325). That fall, General John Sullivan burned down 40 Iroquois towns and destroyed 160,000 bushels of corn. White American forces attacked one town and "put to death all the women and children, excepting some of the young women, whom they carried away for the use of their soldiers and were afterwards put to death in a more shameful manner"' (Kiernan 2007: $325)$.

After becoming President in 1801, Thomas Jefferson continued and intensified terrorism and war on indigenous Americans; he dispatched his general, George Rogers Clark, and the U.S. Army to attack, terrorize, and destroy the Cherokee, Shawness, Peankeshaw, Ouabash, Kickapoes, Mingoes, Munsies, Windots, and Chickasaws (Kiernan 2007). Jefferson wrote a letter to John Page describing "even friendly Indians as 'a useless, expensive, 
ungovernable ally" (Kiernan 2007: 320). While governor of Virginia, Jefferson ordered attacks on Cherokees. The forces of Arthur Campbell destroyed over " 1,000 houses of the over hill Cherokees" in 1780, and the next year, John Sevier "burned fifteen Middle Cherokee towns," while the year after, his son participated in another attack, reporting "we destroyed their towns, stock, corn, [and] everything they had" (Kiernan 2007: 325). After purchasing Louisiana from France in 1803, Jefferson promoted the policy of forcefully removing of indigenous peoples from their territories. In the letter he wrote to the German scholar Alexander von Humboldt in 1812, Jefferson (1813: 792-93) said: "The confirmed brutalization, if not extermination of this race in our America is therefore to form an added chapter in the English history of the same colored man in Asia, and of the brethren of their own color in Ireland and wherever else Anglo-mercantile cupidity can find a two-penny interest in deluging the earth with blood."

Similarly, Andrew Jackson continued the process of terrorizing and exterminating indigenous Americans after he was elected president in 1828. The takeover and plundering of the lands of indigenous peoples were intensified through terrorism and racial/ethnic cleansing in states like Mississippi, Georgia, and Alabama. Jackson informed the indigenous peoples that since the federal government did not have power to help them, they should move to a new territory and abandon their homelands. Supporting the forced removal of the indigenous Americans and the dispossession of their homelands, Jackson, in a State of the Union Address, said:

What good man would prefer a country covered with forests and ranged by a few thousand savages to our extensive Republic, studded with cities, towns, and prosperous farms, embellished with all the improvements which art can devise or industry execute, occupied by more than 12,000,000 happy people, and filled with all the blessing of liberty, civilization, and religion?

In the same speech, he professed the inevitability of the extinction of indigenous peoples to make room for the civilized people (Perdue and Green 2005: 127). One of the most shocking examples of colonial terrorism and racial cleansing through forced removal was practiced on the Cherokee nation. "With the dispossession of the Cherokee Nation via the Trail of Tears," Amy H. Sturgis (2007: 65) notes, "the previous relocations of the Choctaw, Creek, and Chickasaw Nations, and the defeat and ejection of the Seminole Nation, new U.S. policies toward Native America were established."

The United States expropriated the lands of indigenous American peoples and created for them what was known as "an Indian Territory." In addition to forced relocation, the United States destroyed the institutions of indigenous Americans. The U.S. government in Mississippi abolished the government of Choctaws in 1830 and forced them to move to Oklahoma between 1830 and 1833, resulting in the deaths of many. Similarly, in Alabama the government, through various forms of repression, including terrorism, forced the Creeks to surrender all their lands by breaking their resistance. In 1836, the Creek men were "placed in irons and their wailing women and children - a total of 2,495 people-were transported to Oklahoma and, literally naked, without weapons or cooking utensils, were dumped there to live or die" (Debo 1995: 119). In the next year, 543 of them were hunted by the military and dragged to the new territory. Those who remained in Alabama were "hanged for participating in the "uprising' and others were reduced to slavery." Overall, they had lost 45 percent of their population (Debo 1995: 119-120). Continuing to push the indigenous peoples towards extinction, the United States occupied California, Texas, and Oregon between 1845 and 1848 .

After occupying California in 1845, federal forces, local militia, and settlers began to terrorize and exterminate indigenous peoples. During the California Gold Rush of 1848-1868, 
disease, terror, death, genocide, and holocaust were imposed on indigenous Americans of California; the Chico Courant of July 28, 1866 notes, "it is a mercy to the red devils to exterminate them, and a saving of many white lives Treaties are played out--there is one kind of treaty that is effective--cold lead" (Trafzer and Hyer 1999: 1). Colonial terrorism and genocidal massacres also took place on the Great Plains. Texas declared its independence from Mexico in 1836, and its government, militia, and settlers exterminated almost 20,000 indigenous Americans (Kiernan 2007: 334-49). With the annexation of Texas in 1846, the extermination of indigenous peoples continued, as the new state's territory was expanded in this way. Persifor F. Smith, the U.S. major general, warned: "All predatory Indians, no matter where discovered, will be pursued, attacked, and put to death. It is not advisable to take prisoners" (Kiernan 2007: 349). Those who killed indigenous peoples prospered, as they transferred indigenous lands and other resources to themselves, their states, and the federal government. They killed or relocated the remaining indigenous peoples from Missouri, Kansas, Arkansas, Iowa, Nebraska, and Texas, before moving on to the Apaches of the Southwest. In 1871 the U.S. Congress allocated US $\$ 70,000$ "to collect the Apache Indians of Arizona and New Mexico upon reservations" (Debo 1995: 270).

Like other Native Americans, the Apache resisted - unsuccessfully - colonialism and terrorism. The Geronimo-led resistance of the Apache nation symbolized the violent resistance of indigenous Americans during the second half of nineteenth century; Geronimo was a leader who organized his people and fought fiercely against the colonial Mexican and U.S. governments and settlers in the Apache homeland of what is today Arizona and New Mexico (Davis 1929; Faulk 1969). Like others, the Navajo, the Nez Perce, and the Sioux peoples were removed from their respective homelands. "From such policies came the reservation system, the practice of assigning native peoples to specified federal lands, and the trust system," Amy H. Sturgis (2007: 65) notes, "the practice of the U.S. government holding funds owed to native nations on their behalf, much in the same way as guardians would hold property on behalf of their wards." In order to further dispossess indigenous peoples by breaking up reservations, the United States government passed the Dawes law of February 8, 1887, which privatized and divided reservation lands to heads of a family (160 acres for each family), allowing the sale and transfer of remaining lands to white settlers. Thus we see how colonial terrorism targeted most of the indigenous Americans and their institutions to destroy them and transfer their resources to the colonizers.

Out of about 2,000 indigenous nations, approximately 250 lived in North America, some 350 in Mexico and Central America, and about 1,450 in South America (Josephy 1991). At the time of Columbus's arrival, there were between 72 and 75 million indigenous Americans, and some scholars estimate 100 million or more (Josephy 1991: 6; Stannard 1992: x; Taylor 2002: 4). A few scholars have documented the consequences of EuroAmerican colonialism, various forms of violence including terrorism, and diseases in relation to the extermination of the indigenous populations. As David E. Stannard (1992: x) notes, many "historical demographers have been uncovering, in region upon region, postColumbian depopulation rates of between 90 and 98 percent with such regularity that an overall decline of 95 percent has become a working rule of thumb." Also, some demographers estimated that "the first hundred years of European presence in America brought about the demise of ninety-five percent of the Native population, while others suggest that a death rate of seventy-five percent may be accurate" (Perdue 2005: 18). Generally speaking, for others, the population of the Americas was reduced to about 4.5 million in a few centuries (Thornton 1987: 36, 42). Recently, the size of the indigenous population groups has been increasing. In 1990, from the total population of about 663 million in the American continents, there were about 42 million indigenous Americans, which is about 6 percent of the total population (Pandó 1990). 


\section{The Ideological Justifications of Colonial Terrorism}

The Euro-American colonizers, their descendants, and mainstream scholars have harnessed a variety of rationalizations and discourses to justify the scramble for foreign territories as "fulfillment of a sacred duty to spread their form of civilization to the world" (Bodley 1982: 12). According to Eduardo Galeano, "ideological justifications were never in short supply. The bleedings of the New World became an act of charity, an argument for the faith. With the guilt, a whole system of rationalizations for guilty consciences was devised" (1997: 41). The discourses of Christianity, commerce, culture, civilization, progress, and race or culture were commonly used in rationalizing and justifying colonial terrorism and its consequences. The concept of Christianity combined the heavenly power of God with the earthly power of monarchy or state and the unbounded love for money and became a lethal combination for the destruction indigenous peoples of the Americas. In these ways, the Euro-American colonizers and their descendants have created and maintained a "heavenly world" for themselves and a "hell" for the native peoples.

Missionaries also played a central role in undermining the political, economic, and cultural institutions of the indigenous populations and facilitating their destruction. Pope Alexander VI of Rome set the tone of robbery in the Americas through various forms of violence including terrorism by endorsing the charter that Columbus received from the monarchs of Spain in 1492 (Shiva 1997: 2). John Frederick Schwaller traces this papal involvement:

Alexander VI and his successor Julius II, gave the Spanish monarchs the basis for supervising missionary activities in the newly discovered lands and the means whereby to financially support the activity. Alexander VI issued three bulls $[\ldots]$ The first of these granted to the Spanish monarchs all the powers that the Portuguese enjoyed in their overseas possessions. The second of the three provided the monarchs with a means of a royal tax. The third bull, dating from 1501, granted the Spanish monarchs the right to collect and use ecclesiastical tax, the tithe, in the New World. (2011: 47)

These bulls gave the monarchs control of the colonial possessions and the church by establishing the administrative structure and appointing church officials and paying them salary from the tithe. Consequently, the Catholic Church lost its autonomy and became a tool of colonialism and terrorism in the Americas. In the process, the monarchs, most missionaries, and religious leaders connected Christianity, European civilization, and capitalism to the project of colonial terrorism and the dispossession of the native peoples.

Spanish clergies accompanied the conquerors like Hernán Cortês and Hernando Pizarro and participated in all forms of colonial projects. The Spaniards and other Europeans claimed that they were sent by God to spread Christianity; but, in reality, they "fostered violent hatred and racism, massacres, and the plundering and dispossession of the Indians" (Josephy 1991: 5). The colonial settlers and their descendants had manufactured lies, deceptions, illusions, and misinformation about the indigenous Americans to hide their crimes against humanity. The claim of discovery and the ideological rationalizations of civilization, racism, culture, and Christianity helped in creating unity against indigenous peoples and controlling internal populations after colonial state formations. Peoples or groups that engage in any large-scale oppression, discrimination, segregation, enslavement, and massive political violence for annihilation use dehumanizing name-calling, such as deficient human beings or less human, animal or beast, parasitic creature, infectious disease, waste product, and non-person (Bernnan 1995). The settlers called indigenous Americans inferior, 
not human, untamable carnivorous animals, vermin, pestilence, anthropological specimen, the dregs and garbage of the earth, and non-persons (Bernnan 1995: 7).

Semantic warfare is "a deliberate and unremitting phenomenon usually under-girded by fully elaborate systems of concepts, beliefs, and myths," and groups "who control language control thought and eventually semantic corruption leads to the adulteration of thought itself" (Bernnan 1995: 8, 12).

With time, these "fully elaborate systems of concepts, beliefs, and myths" have become the ideological foundation of society and started to corrupt the minds of the public. According to Aleksandr Solzhenitsyn (1973-74: 173-74), "Ideology - that is what gives evildoing its long-sought justification and gives the evildoer the necessary steadfastness and determination. That is the social theory which helps [...] acts seem good instead of bad in [one's] own and others' eyes, so that [one] won't hear reproaches and curses but will receive praise and honors." Individuals like Columbus and most religious and political figures are celebrated today, and very few pay attention to the reality of their deeds. The ideologies of racism, Christian fundamentalism, and Euro-American centrism thus deny the public the opportunity to learn about the humanity, cultures, and histories of indigenous American peoples. Today, elites who run and maintain institutions such as governments, schools, churches, and colleges, publishing houses, as well as reporters, broadcasters, columnists, editors, bureau chiefs, and executives, writers, artists, producers, and actors serving as "gatekeepers of information who determine what ideas, perceptions, attitudes, and values are allowed into the public domain" have continued to objectify indigenous peoples (Bernnan 1995: 17).

In history books, films, and other forms of media, indigenous Americans have been wrongly portrayed "as wild savages who wantonly slaughtered innocent white settlers and displayed their scalps as an exhibitions of hunting acumen" (Bernnan 1995: 58-59). The legitimate struggles of indigenous peoples for resistance, survival, and national liberation have been also distorted and criminalized while the criminal acts of the settlers and their descendants have been rationalized and glorified. The colonizers and their descendants have maintained the identities of the dominant population groups and their power and privileges through policy formulation and implementation by socially and culturally constructing the concepts of race and racism (Jalata 2001). "Scientific" claims have been made to promote personal and group interests at the cost of humanity. The ideology of white racism portrayed indigenous peoples as savage and barbaric in order to rationalize crimes against humanity and exonerate the executioners. The Euro-Americans have actually only been superior in their destructive weapons and in their greed-inspired cruelty: according to William Bernnan (1995: 57), "The wholesale departure of Native Americans from the landscape of North America was not the inevitable result of a primitive, inferior race naturally wilting before the march of progress and modern civilization. It was due, instead, to a deliberate and pervasive policy of $[\ldots]$ extermination."

Indigenous Americans never passively accepted all these crimes against them. Indeed, they continue to struggle against the violent occupation of their homelands and continents. Several indigenous national movements have emerged and developed since the $1950 \mathrm{~s}$ to change resistance struggles to protests and revolutions in order to restore their humanity, collective land rights, to have access to bilingual and intercultural education, to introduce constitutional reforms, and to promote multicultural democracy by emphasizing economic and social equality and justice (Van Cott 2007, 2009; Fischer 2009; Langer and Muñoz 2003; Warren and Jackson 2002; Postero and Zamose 2006; Hall and Fenelon 2009). "Over the fifty years or so, American Indians have become emblematic of movements to reestablish their legitimate status as sovereignty" (Hall and Fenelon 2009: 91). Native Americans and "First Nations" of Canada have struggled for self-determination. Other indigenous 
organizations, such as the Confederation of Indigenous Nationalities of Ecuador, the Interethnic Association of the Development of Peruvian Rainforest, the United Multiethnic People of Amazonas, and others have participated in liberation struggles in Latin American countries to introduce some changes on individual and collective rights and in the areas of engaging citizens in public policy decision-making and in holding leaders accountable. Donna Lee Van Cott (2007: 9-10) notes that Latin America's indigenous social movement and parties offer a "unique perspective for addressing democratic deficiencies, as well as the capacity to mobilize social capital for democratic ends and to forge consensus on common political projects. They are expanding public expectations of democracy by insisting on greater participation, the reduction of inequality, and the protection of collective rights." Furthermore, indigenous peoples of the world and their activists have intensified their struggle for self-determination, multinational democracy, the rule of law, and legal protection (Wilmer 1993). Transnational indigenous activism and social movements facilitated the formation of the Permanent Forum on Indigenous Issues in 2000 in the United Nations, a development that can be seen as contesting the legal sovereignty of UN member states (Morgan 2007).

Throughout the Americas, several changes have taken place since the $1970 \mathrm{~s}$, including the election of an indigenous president of Bolivia and an official apology from the Canadian government for at least some of its mistreatment of native peoples. Other oppressed communities and progressive forces have started to form political alliances with indigenous movements to fight against reactionary regimes and the policies of neoliberalism (Fischer 2009). Similarly, some progressive religious leaders and figures in the Roman Catholic Church and missionaries in Latin America have changed their religious and political positions toward indigenous peoples and have begun to support their movements for social, political, economic, and human rights (Domínguez 1994). In the mid-twentieth century, the Catholic "church began to develop its own social change while remaining at arms length from the political process. Some priests, however, embraced radical political movements and revolutionary struggle. The period also saw the beginning of a way of doing theology, which became known as liberation theology" (Schwaller 2011: 11-12). At this moment, however, the Catholic Church is facing internal crises and lacks an active and progressive political agenda regarding the poor in general and indigenous peoples in particular.

\section{Conclusion}

Today some descendants of colonialists have become rich and powerful because of intergenerational upward mobility based on the exploitation of the resources of indigenous peoples. Therefore, all powerful individuals and groups should critically interrogate themselves morally, ethically, culturally, socially, religiously, philosophically, and politically in order to develop their full humanness by exposing the crimes committed against humanity. Refusing to recognize these crimes is tantamount to continue to commit similar crimes by supporting unjust and corrupt political and ideological practices. For whatever reasons, engaging in or supporting a system that has been annihilating certain human groups is morally and ethically wrong. While some descendants of the settlers own lands and other economic resources, businesses, as well as organizations and institutions, including governments, corporations, education, the media, and healthcare systems, the surviving indigenous peoples live an impoverished life on reservations and in cities in North America and in rural and ghetto areas of South and Central America. By understanding the devastating effects of colonial terrorism and genocide on the indigenous Americans, the present generations of colonial settlers should recognize the crimes against humanity and start to 
uplift the surviving indigenous peoples by offering apologies, making restitution, and by promoting their struggles for self-determination and multicultural democracy.

The descendants of executioners and their victims need to develop a multiculturalcentric knowledge of history and use this to construct a personal and collective future based on the principles of multinational egalitarian democracy, self-determination, and the rule of law. To do this, governments and other institutions need to recognize and incorporate the authentic histories, cultures, and humanity of indigenous Americans in all levels of education. Celebrating the contributions of indigenous American peoples, recognizing and making restitution for the crimes committed, and accepting the diversity of these cultures will contribute to the full development of humanity by resurrecting the damaged humanity of the executioners and the victims. Without critically and thoroughly understanding the processes of capitalist broadening and incorporation, and without adequately learning about the crimes of colonial terrorism, we cannot confront the moral, ethical, philosophical, and political contradictions in the capitalist world-system and move towards establishing a just and truly egalitarian democratic world order. For more understanding of the human agencies of the indigenous peoples, future research is necessary on their resistances, movements, organizations and mobilizations in the framework of world-systems approach and analysis. 


\section{References}

Arendt, Hannah. 1958. The Origins of Totalitarianism. $2^{\text {nd }}$ edition. Cleveland: World Publishing Co.

Algeria, Ricardo. 1997. "The Study of Aboriginal Peoples: Multiple Ways of Knowing." Pp. 9-19 in The Indigenous People of the Caribbean, edited by Samuel M.Wilson. Gainesville: University of Florida Press.

Alvarez, Sonia and A. Escobar, eds. 1992. The Making of Social Movements in Latin America: Identity, Strategy, and Democracy. Boulder, CO: Westview Press.

Barta, Tony. 2007. "On Pain of Extinction: Laws of Nature and History in Darwin, Marx, and Arendt." Pp. 89-105 in Hannah Arendt and the Uses of History: Imperialism, Nation, Race, and Genocide, edited by Richard H. King and Dan Stone. New York: Berghahn Books.

Brennan, William. 1995. Dehumanizing the Vulnerable: When Word Games Take Lives. Chicago: Loyola University Press.

Blackhawk, Ned. 2006. Violence Over the Land: Indians and Empires in the Early American West. Cambridge, MA: Harvard University Press.

Blakeley, Ruth. 2009. State Terrorism and Neoliberalism: The North in the South. New York: Routledge.

Berberoglu, Berch. 2003. Globalization of Capital and Nation-States. Lanham, MD: Rowman \& Littlefield Publishers.

Bodley, John H. 1982. Victims of Progress. Redwood City, CA: Benjamin-Cummings Publishing Co.

Brysk, Alison. 2000. From Tribal Village to Global Village, Indian Rights and International Relations in Latin America. Stanford: Stanford University Press.

Carlson, Jon D. 2001. "Broadening and Deepening: Systemic Expansion, Incorporation and the Zone of Ignorance." Journal of World-Systems Research VII(2/Fall): 225-263.

-----. 2002. "The 'Otter-Man' Empires: The Pacific Fur Trade, Incorporation and the Zone of Ignorance." Journal of World-Systems Research VIII(3/Fall): 390-442.

Clark, A. Kim and Marc Becker, eds. 2007. Highland Indians and the State in Modern Ecuador. Pittsburgh, PA: University of Pittsburgh Press.

Cooper, H. H. A. 2001. "Terrorism: The problem of definition revisited." American Behavioral Scientist 44: 881-893.

Cohen, J. M., ed. and trans. 1969. Christopher Columbus: The Four Voyages. London: Penguin Books.

Colson, Elizabeth. 1992. "Conflict and Violence." Pp. 277-287 in The Paths to Domination, Resistance and Terror, edited by Carolyn Nordstrom and JoAnn Martin. Berkeley: University of California Press.

Connell, Raewyn. 2007. "The Northern Theory of Globalization." Sociological Theory 25: 368-385.

Córdoba, Juan-Carlos. 2007. "Malthus to Romer: On the Colonial Origins of the Industrial Revolution." Version for discussion, Rice University. Accessed September 20, 2012 (http://ideas.repec.org/p/pra/mprapa/4466.html).

Chalk, Frank and Kurt Jonassoh. 1990. History and Sociology of Genocide: Analyses and Case Studies. New Haven, CT: Yale University Press.

Chomsky, Noam. 1993. Year 501: The Conquest Continues. Boston: South End Press.

Curtis, Mark. 1995. The Ambiguities of Power: British Foreign Policy Since 1945. London: Zed Books LTD.

-----. 1998. The Great Deception: Anglo-American Power and World Order. London: Pluto Press.

Davis, Britton. 1929. The Truth About Geronimo. New Haven, CT: Yale University Press. 
De Las Casas, Bartholomé. 1971. History of the Indies. Edited and translated by Andrée Collard. New York: Harper \& Row.

-----. 1992. A Short Account of the Destruction of the Indies. Edited and translated by Nigel Griffin. London: Penguin Books.

Debo, Angie. 1995. A History of the Indians of the United States. London: Pimlico Edition.

Diamond, Jared. 1999. Guns, Germs, and Steel: The Fates of Human Societies. New York: W. W. Norton \& Company.

Dickason, Olive P. 2002. Canada's First Nations. $3^{\text {rd }}$ Edition. New York: Oxford University Press.

-----. 2006. A Concise History of Canada's First Nations. New York: Oxford University Press.

Domínguez, Jorge I., ed. 1994. The Roman Catholic Church in Latin America. New York: Garland Publishing, Inc.

Dunaway, Wilma A. 1994. "The Southern Fur Trade and the Incorporation of Southern Appalachia into the World-Economy, 1690-1763." Review XVII(2/Spring): 215-242. 1996a. The First American Frontier: Transition to Capitalism in Southern Appalachia, 1700-1860. Chapel Hill: University of North Carolina Press.

-----. 1996b. "The Incorporation of Mountain Ecosystems into the Capitalist World-System." Review XIX(4/Fall): 355-381.

-----. 1997. "Rethinking Cherokee Acculturation: Agrarian Capitalism and Women's Resistance to the Cult of Domesticity, 1800-1838." American Indian Culture and Research Journal 21(1): 155-192.

Enders, Walter and Todd Sandler. 2006. The Political Economy of Terrorism. New York: Cambridge University Press.

Eisenstein, Hester. 2001. "After 9/11: Globalization and the Events of September 11." Journal of the Research Group on Socialism and Democracy 16: 131-136.

Elkins, Caroline. 2005. Imperial Reckoning: The Untold Story of Britain's Gulag in Kenya. New York: Henry Holt and Company.

Elliot, J. H. 1996. Imperial Spain 1469-1716. New York: Mentor Books.

Escobar, Arturo. 2004a. "Development, Violence and the New Imperial World Order." Development 47: 15-21.

-----. 2004b. "Beyond the Third World: Imperial Globality, Global Coloniality and AntiGlobalisation Social Movement." Third World Quarterly 25: 207-230.

Faulk, Odie B. 1969. The Geronimo Campaign. New York: Oxford University Press.

Farmer, Paul. 2004. "Anthropology of Structural Violence." Current Anthropology 45: 305325.

-----. 2005. Pathologies of Power. Berkeley: University of California Press.

Fenn, E. A. 2000. "Biological Warfare in Eighteenth-Century North America." Journal of American History 86(4):552-58.

Fenelon, James V. 1997. "From Peripheral Domination to Internal Colonialism: SocioPolitical Change of the Lakota on Standing Rock," Journal of World-Systems Research 3(2/Spring): 259-320.

-----. 1998. Culturicide, Resistance, and Survival of the Lakota ('Sioux Nation'). New York: Garland Publishing, Inc.

Ferguson, R. Brian and Neil L. Whitehead, eds. 1992. War in the Tribal Zone. Santa Fe, NM: School of American Research Press.

Fischer, Edward F., ed. 2009. Indigenous Peoples, Civil Soceity, and the Neo-liberal State in Latin America. New York: Berghahn Books.

Frank, A. Gunder. 1978. World Accumulation 1492-1789. New York: Monthly Review Press. 
Galeano, Eduardo. 1997. Opens Veins of Latin America: Five Centuries of the Pillage of a Continent. New York: Monthly Review Press.

Green Left. 1992. Accessed September 17, 2012 (www.greenleft.org.au/node/2894).

Goodwin, Jeff. 2006. "A Theory of Categorical Terrorism.” Social Forces 84(4): 2027-2046.

Hall, Thomas D. 1989a. Social Change in the Southwest, 1350-1880. Lawrence: University Press of Kansas.

-----. 1989b. "Is Historical Sociology of Peripheral Regions Peripheral?" Pp. 349-372 in Studies of Development and Change in the Modern World, edited by Michael $\mathrm{T}$. Martin and Terry R. Kandal. New York: Oxford University Press.

-----. 1993. Book review of War in the Tribal Zone: Expanding States and Indigenous Warfare, edited by R. Brian Ferguson and Neil L. Whitehead. 1992. American Indian Culture and Research Journal 17(2): 239-245.

-----. 1996. "The World-System Perspective: A Small Sample from a Large Universe." Sociological Inquiry 66(4): 440-454.

Hall, Thomas D., ed. 2000. A World-Systems Reader. New York: Rowman \& Littlefield Publishers, Inc.

Hall, Thomas D. and James V. Fenelon. 2004. "The Futures of Indigenous Peoples: 9-11 and the Trajectory of Indigenous Survival and Resistance." Journal of World-Systems Research X(1/Winter): 153-197.

-----. 2009. Indigenous Peoples and Globalization: Resistance and Revitalization. 5th edition. Boulder, CO: Paradigms Publishers.

Harvey, David. 2005. A Brief History of Neoliberalism. New York: Oxford University Press.

-----. 2007. "Neoliberalism as Creative Destruction." Annals of the American Academy of Political and Social Science 610: 22-44.

Hollis, Shirley. 2005. "Contact, Incorporation, and the North American Southeast." Journal of World-Systems Research XI(1/July): 95-130.

Horowitz, Irving Louis. 2002. Taking Lives: Genocide and State Power. London: Transactions Publishers.

Jackson, Richard. 2009. "The Study of Terrorism after 11 September 2001: Problems, Challenges and Future Developments." Political Studies Review 7: 171-184.

Jalata, Asafa. 2000. "US-Sponsored Ethiopian-Democracy and State Terrorism." Pp. 64-89 in Crisis and Terror in the Horn of Africa: Autopsy of Democracy and Human Rights, edited by Pietro Toggia, Pat Lauderdale, and Abebe Zegeye. Burlington, VT: Ashgate.

-----. 2001. Fighting Against the Injustice of the State and Globalization. New York: Palgrave.

-----. 2006. "Terrorism and Globalization: The Cases of Ethiopia and Sudan." Pp. 79-102 in Terrorism: A New Testament. Toronto: de Sitter Publications.

Jefferson, Thomas. 1813. "Jefferson to Alexander von Humboldt, Dec. 6" in Helmut de Terra, "Alexander von Humboldt's Correspondence with Jefferson, Madison, and Gallatin." Proceedings of the American Philosophical Society 103(6): 792-93.

Josephy, Jr., Alvin M., ed. 1991. "Introduction: The Center of the Universe." American 1492: The World of the Indian Peoples before the Arrival of Columbus. New York: Vintage Books.

Jonassohn, Kurt. 1998. Genocide and Gross Human Rights Violations: In Comparative Perspective. New Brunswick, NJ: Transaction Publishers.

Keck, Margaret E. and Kathryn Sikkink. 1999. Activists Beyond Borders: Advocacy Networks in International Politics. Ithaca, NY: Cornell University Press.

Kiernan, Ben. 2007. Blood and Soil: A World History of Genocide and Extermination from Sparta to Darfur. New Haven, CT: Yale University Press. 
Kuper, Leo. 1981. Genocide. New Haven, CT: Yale University Press.

Langer, Erick D. and Elena Muñoz, eds. 2003. Contemporary Indigenous Movements in Latin America. Wilmington, DE: Scholarly Resources Inc.

Lemkin, Raphael. 1944. Axis Rule in Occupied Europe. Washington, DC: Carnegie Endowment for International Peace.

Loewen, James W. 1995. Lies My Teacher Told Me. New York: The Free Press.

Marx, Karl. 1967. Capital. New York: International Publishers.

McMichael, Philip. 2006. Development and Social Change: A Global Perspective. $4^{\text {th }}$ edition. Thousand Oaks, CA: Pine Forge.

Metcalf, Alida C. 2005. Go-between and the Colonization of Brazil, 1500-1600. Austin: The University of Texas.

Morgan, Rhiannon. 2007. "On Political Institutions and Social Movement Dynamics: The Case of the United Nations and the Global Indigenous Movement." International Political Science Review 28: 273-292.

Pando, J. 1990. "Indigenous Peoples." International Labour Organization. (http://www.ilo.org/public/english/region/ampro/mdtsanjose/indigenous/cuadro.htm).

Perdue, Theda. 2005. The Cherokees: Indians of North America. Philadelphia: Chelsea House Publishers.

Perdue, Theda and Michael D. Green. 2005. The Cherokee Removal: A Brief History with Documents. $2^{\text {nd }}$ edition. New York: Bedford/St. Martins.

Postero, Nancy Grey and Leon Zamosc, eds. 2006. The Struggle of Indigenous Rights in Latin America. Portland, OR: Sussex Academic Press.

Rajagapol, Balakrishnan. 2003. International Law from Below. New York: Cambridge University Press.

-----. 2006. "Counter-Hegemonic International Law: Rethinking Human Rights and Development as a Third World Strategy." Third World Quarterly 27: 767-783.

Sawyer, Suzana. 2004. Crude Chronicles: Indigenous Politics, Multinational Oil, and Neoliberalism in Ecuador. Durham, NC: Duke University Press.

Schwaller, John Frederick. 2011. The History of the Catholic Church in Latin America: From Conquest to Revolution and Beyond. New York: New York University Press.

Sharlack, Lisa. 2002. "State Rape: Sexual Violence as Genocide." Violence and Politics: Golobalization's Paradox, edited by K. Worcester, Sally Avery Bermanzohn, and Mark Ungar. New York: Routledge.

Shiva, Vandana. 1997. Biopiracy: The Plunder of Nature and Knowledge. Boston: South End Press.

Schmid, Alex P. 1991. "Repression, State Terrorism and Genocide: Conceptual Clarifications." Pp. 23-37 in State Organized Terror, edited by P. Timothy Bushnell, V. Shlapentokh, C. K. Vanderpool, and J. Sundram. Boulder, CO: Westview.

Sloan, John W. 1984. "State Repression and Enforcement Terrorism in Latin America." Pp. 83-98 in The State as Terrorist: The Dynamics of Governmental Violence and Repression, edited by Michael Stohl and George A. Lopez. Westport, CT: Greenwood Press

Solzhenitsyn, Aleksandr. 1973/74. Gulag Archipelago, 1918-1956. New York: Harper.

de Sousa Santos, Bonaventura. 2007. "Beyond Abyssal Thinking: From Global Lines to Ecologies of Knowledge." Review XXX(1): 45-89.

Stannard, David E. 1992. The Conquest of the New World: American Holocaust. Oxford: Oxford University Press.

Steven, Samuel Totten and Leonard Jacobs, eds. 2002. Pioneers of Genocide Studies. London: Transaction Publishers. 
Sturgis, Amy H. 2007. The Trail of Tears and Indian Removal. Westport, CT: Greenwood Press.

The Healing Center. 2007. "The Taino Indians/Native Americans of the Caribbean." Accessed September 22, 2012 (http://www.healing-arts.org/spider/tainoindians.htm).

Taylor, Alan. 2002. American Colonies. New York: Penguin.

Trafzer, Clifford E. and Joel R. Hyer, eds. 1999. Exterminate Them: Written Accounts of the Murder, Rape, and Slavery of Native Americans during the California Gold Rush, 1848-1868. East Lansing: Michigan State University Press.

Thornton, Russell. 1987. American Indian Holocausts and Survival: A Population History Since 1942. Norman: University of Oklahoma Press.

Yashar, Deborah J. 2005. Contesting Citizenships in Latin America. Cambridge: Cambridge University Press.

Van Cott, Donna Lee. 2007. "Latin America's Indigenous Peoples." Journal of Democracy 18(4): 127-142.

-----. 2009. Radical Democracy in the Andes. New York: Cambridge University Press.

Warren, Kay B. and Jean E. Jackson, eds. 2002. Indigenous Movements, Self-Representation, and the State in Latin America. Austin: Texas University Press.

Wilson, Samuel. 1997. "Introduction to the Study of the Indigenous People of the Caribbean." Pp. in The Indigenous People of the Caribbean, edited by Samuel M. Wilson. Gainesville: University of Florida.

Wilmer, Franke. 1993. The Indigenous Voice in World Politics. Newbury Park, CA: Sage Publications.

Whitehead, Neil L. 1992. "Tribes Make States and States Make Tribes: Warfare and the Creation of Colonial Tribes and States in Northeastern South America." In War in the Tribal Zone: Expanding States and Indigenous Warfare. Santa Fe, NM: School of American Research Press.

-----. 1993. "Ethnic Transformation and Historical Discontinuity in Native Amazonia and Guyana, 1500-1900." L'Homme XXXIII (2-4: 285-305.

-----, ed. 2004a. "On the Poetics of Violence." Pp. 55-77 in Violence. Santa Fe, NM: School of American Research Press.

-----, ed. 2004b. "Introduction: Cultures, Conflicts, and the poetics of Violent Practice." Pp. 3-24 in Violence, edited by Neil L. Whitehead. Santa Fe, NM: School of American Research Press.

Wolf, Eric. 1982. Europe and People Without History. Berkeley: University of California Press.

Zinn, Howard. 2003. A People's History of the United States: 1492-Present. New York: Harper Collins Publishers. 